\title{
Performance of Footing on MICP Induced Slope
}

\author{
Dr. S. S. Pusadkar ${ }^{1}$, Rewati N. Tawalare ${ }^{2}$, Dr. A. I. Dhatrak ${ }^{3}$ \\ ${ }^{1}$ (HOD, Civil Engineering Dept., Government College of Enginnering, Jalgaon, Maharashtra, India) \\ ${ }_{2}^{2}$ (PG Student, Civil Engineering Dept., Government College of Enginnering, Amravati, Maharashtra, India) \\ ${ }^{3}$ (Associate Professor, Civil Engineering Dept., Government College of Enginnering, Amravati, Maharashtra, \\ India)
}

\begin{abstract}
Microbial-induced calcite precipitation (MICP) is a novel ground improvement method to increase strength and stiffness of sand using natural biogeochemical processes. This paper describes the application of MICP in slope improvement. A strip footing was tested in a laboratory by conducting a model load test on sand slope of 1.5H: $1 \mathrm{~V}$. The slope was treated by injecting bacteria (S. Pasteurii) and cementation solution $\left(\mathrm{CaCl}_{2}+\right.$ Urea) at $2 \mathrm{M}$ concentration in a grid pattern of $100 \mathrm{~mm} \times 100 \mathrm{~mm}$. These slopes were allowed to cure for the incubation period of 14 and 28 days. The load tests were conducted for three locations of footing on edges at a distance measured from slope crest as $O B, B$ and $2 B$. The results indicated that the bearing capacity of footing on slope increased significantly after MICP treatment. The bearing capacity of slopes cured for 28 days was found to be maximum.
\end{abstract}

Keywords: biogeochemical, MICP, incubation

\section{Introduction}

A conventional solution to improve the bearing capacity of slope is to remove part of the existing weak soil and to replace it by granular soil (partial replacement), root reinforcement or geosynthetic reinforcement can be provided in the sand fill layer and grouting is used which often requires high pressure to inject the grouts due to their high viscosity or fast hardening time. In order to address the disadvantages of current slope stability techniques one could look at natural alternatives. Interest in the use of biological technologies in geotechnical engineering has been rising over the past few years. Microbial induced carbonate precipitation (MICP) has unique characteristics with potential advantages over conventional soil improvement techniques. MICP addition in soil increases the shear strength and stiffness. The technique introducing aerobically cultivated bacteria with highly active urease enzyme into soil, harnessing the urease enzyme to catalyze the hydrolysis of urea to produce ammonium and carbonate ions. In sandy soils, bio-cementation improves the shear strength of soil through the production of soil particle-binding materials, as a result of introducing bacteria and cementation reagents into the soil. Calcium carbonate (calcite) is an element observed in bio-cementation process whose formation is commonly found in nature. The bacteria's suitable for MICP application should be able to catalyze the urea hydrolysis and usually urease positive bacteria. The typical urease positive bacteria are genera Bacillus, Sporosarcina, Spoloactobacilus, Clostridium and Desulfotomaculum. S. Pasteurii is a more common type of bacteria used to precipitate calcium carbonate. In this investigation, an attempt has been made to investigate the effect of Microbial Induced Calcite Precipitation (MICP) on the performance of slopes. The use of microbes in improvement of slopes will be investigated in terms of quantity, incubation period, and methodology. A load test on strip footing placed on slope was conducted to evaluate the failure load with or without injection of bacteria. The various parameters considered for present study were the concentration of bacteria, method of mixing of bacteria, incubation period, footing distance from crest $(0 \mathrm{~B}, \mathrm{~B}, 2 \mathrm{~B})$ under vertical point load for a slope of $1.5 \mathrm{H}: 1 \mathrm{~V}$.

\section{Literature Review}

A brief review of previous studies on MICP is carried out. It includes methodology and parameters adopted by researchers and brief conclusions of their study. The objective of this review was to identify the gap in research which was further considered for present research work. Keskin and Laman ${ }^{1}$ (2012) experimentally investigated the ultimate bearing capacity of strip footing on sand slope. The results showed that the ultimate bearing capacity increased with increase in setback distance, relative density of sand, footing width and decreased in slope angle. At a setback distance of five times of the width of the footing, bearing capacity was remained constant like that of a footing on level ground. Mittal $^{2}$ et al. (2009) investigated experimentally the behavior of shallow surface footings on reinforced and unreinforced earth slopes. The results indicated that the bearing capacity of strip footings on sloping ground can be significantly increased by the inclusion of reinforcement layers in the slope which was greatly affected by the type of reinforcement, distance of footing from the edge of slope, depth of top layer and depth of reinforcement zone. DeJong ${ }^{3}$ et al. (2006) achieved microbially induced calcite precipitation (MICP) using the microorganism Bacillus pasteurii (ATCC 6453). The 
microbes were introduced to the sand specimens in a liquid growth medium amended with urea and a dissolved calcium source. A series of isotropically consolidated undrained compression (CIUC) triaxial tests indicated that the MICP-treated specimens exhibit a higher initial shear stiffness and ultimate shear capacity than untreated loose specimens. Mortensen and DeJong ${ }^{4}$ (2011) studied the strength and stiffness of loose sand deposits using S. Pasteurii (ATCC 1376). Triaxial tests were used to evaluate the evolution of stiffness and strength in specimens. The MICP treated specimen exhibited an increase of approximately 1.3 times the peak shear strength of the loose untreated specimen.

Soon $^{5}$ et al. (2012) examined the factors affecting the MICP in soil with $0.25 \mathrm{M}$ of bacteria solution (B. Magaterium) that underwent different treatment conditions and were tested for their shear strength and permeability. The results showed that both shear strength and impermeability of residual soil improved significantly upon MICP treatment with increasing soil density. Cheng ${ }^{6}$ et al. (2013) investigated the geotechnical properties of sand bio-cemented under different degrees of saturation using B. Pasteurii (MCP 11 DSMZ 23526). The results indicated that higher soil strength can be obtained at similar $\mathrm{CaCO}_{3}$ content when the treatment was performed under a low degree of saturation and the bio-cemented samples have higher strength and lower hydraulic conductivity in the range of lower cement agent. Park ${ }^{7}$ et al. (2014) employed Sporosarcina Pasteurii to enhance the strength of weakly cemented soil and fill its voids. Results show that the UCS of the specimen decreased after increasing the number of injections of microbe medium. The UCS of the specimen treated once with the microbes showed a 5\% increase compared to the untreated specimen. Soon and Lee ${ }^{8}$ (2014) explored the viability of the MICP technique for improving the engineering properties of a typical tropical residual soil. The results showed that the improvement in the engineering properties of the MICPtreated residual soils was comparable to those of treated fine sands. Shear strength increased and hydraulic conductivity reduced by 69 and $90 \%$, respectively with the minimum calcite content of $1.0 \%$. The literature shows that MICP treated soil shows improvement in strength of soil and footings on slopes affect the stability of slopes or bearing capacity of footing resting on slope reduces. In order to increase the bearing capacity of footing on slope, here an attempt has been made to study the effect of MICP on sand slope performance, by virtue of studying the bearing capacity of strip footing on slope crest.

\subsection{Sand}

\section{Material}

Kanhan sand available in Nagpur in Maharashtra was used for the present study. It is in angular shape, uniform yellow color with small proportion of flint stone and shown in Fig. 1. The engineering properties of sand are listed in TABLE 1.

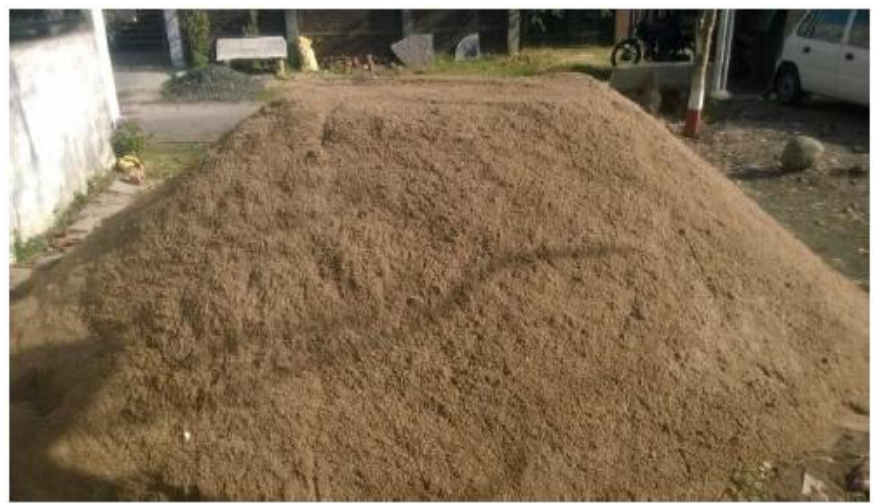

Figure 1: Kanhan Sand

Table 1: Index Properties of Sand

\begin{tabular}{|c|c|}
\hline Properties & Values \\
\hline Specific gravity & 2.69 \\
\hline$\gamma_{\max }\left(\mathrm{kN} / \mathrm{m}^{3}\right)$ & 17.11 \\
\hline$\gamma_{\min }\left(\mathrm{kN} / \mathrm{m}^{3}\right)$ & 15.82 \\
\hline Relative Density $(\%)$ & 40 \\
\hline Angle of internal friction $(\varphi)$ & 47.00 \\
\hline Cohesion $\left(\mathrm{kN} / \mathrm{m}^{2}\right)$ & 0.00 \\
\hline Coefficient of uniformity $\left(\mathrm{C}_{\mathrm{u}}\right)$ & 2.125 \\
\hline Coefficient of curvature $\left(\mathrm{C}_{\mathrm{c}}\right)$ & 1.204 \\
\hline IS classification & $\mathrm{SP}$ \\
\hline
\end{tabular}




\subsection{Bacteria}

Bacillus Pasteurii is most common bacteria which is used for the Microbial Induced Calcite Precipitation (MICP). A bacterial culture of Bacillus Pasteurii (NCIM 2477) was obtained from National Collection of Industrial Microorganism (NCIM), Pune in test tubes as shown in Fig. 2. It was stored under the $30^{\circ} \mathrm{C}$ in the laboratory. The culture was purely natural.

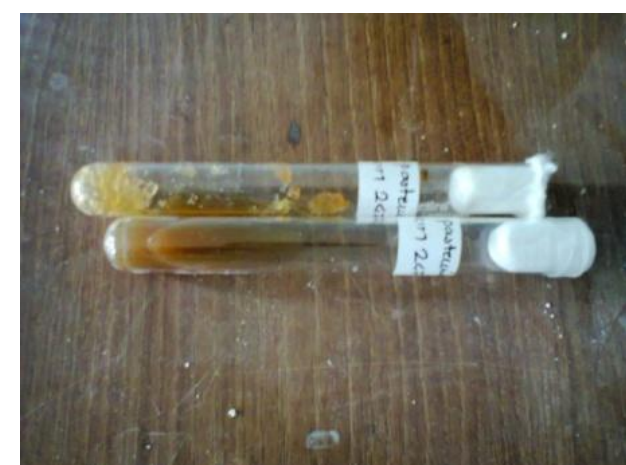

Figure 2: Culture of Bacillus Pasteurii (NCIM 2477)

\subsection{Cementation Solution}

Cementation solution was made by $2 \mathrm{M}$ concentration of urea and $\mathrm{CaCl}_{2}$ by adding in distilled water.

\subsection{Test Box}

The test boxes were made of plywood to accommodate the slope of $1.5 \mathrm{H}: 1 \mathrm{~V}$. The size of box was $1000 \mathrm{~mm} \mathrm{x}$ $425 \mathrm{~mm}$ x $400 \mathrm{~mm}$ with $12 \mathrm{~mm}$ thick plywood and is as shown in Fig. 3 .

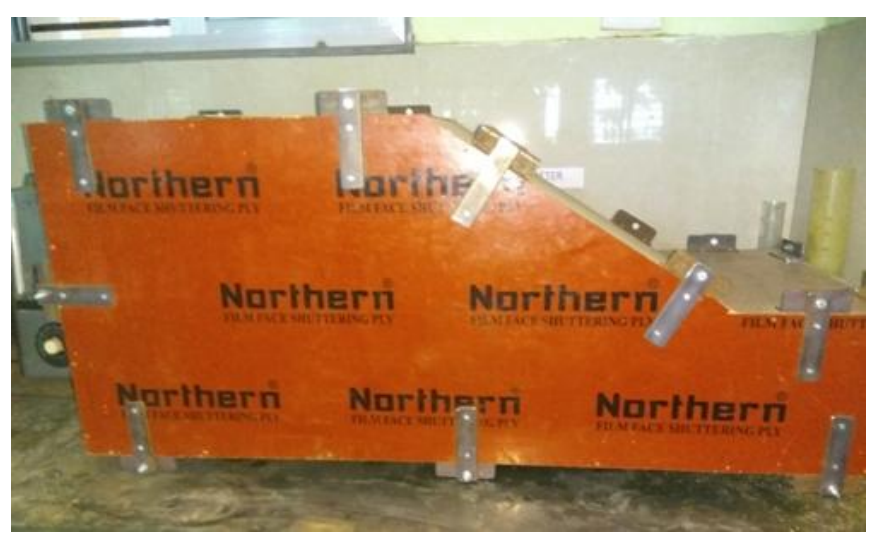

Figure 3: Test box of Slope of 1.5H:1V

\subsection{Strip Footing}

The strip footing was fabricated by using mild steel plate having dimensions $380 \mathrm{~mm}$ x $75 \mathrm{~mm} \times 15 \mathrm{~mm}$. The footing had a little groove at the centre for application of load. The model footing is as shown in Fig. 4.

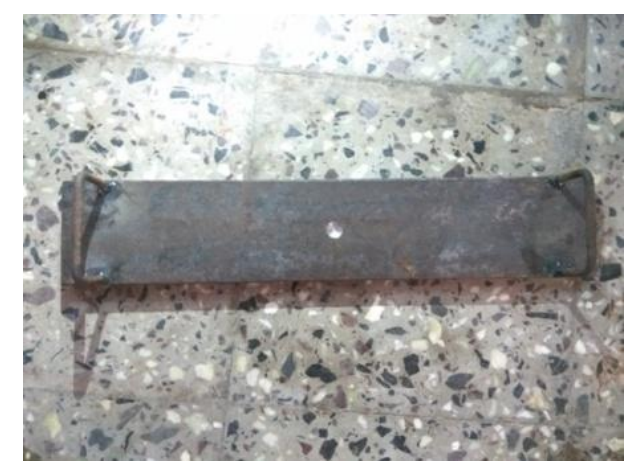

Figure 4: Strip Footing 


\section{Methodology}

A model sand slope with slope $1.5 \mathrm{H}: 1 \mathrm{~V}$ was prepared by using the compaction procedure in layers of $50 \mathrm{~mm}$ thick sand. The inner surfaces of the test box were marked at $50 \mathrm{~mm}$ intervals to make easy the preparation of the sand bed in layers. The sand was compacted in layers. The process continued layer by layer until the height of the slope was reached. The great care had taken to make the slope face so that the relative density remains same throughout the bed. The solution was made by mixing of cultivated bacteria solution and $\mathrm{CaCl}_{2}$ and urea dissolved at $2 \mathrm{M}$ concentration in distilled water (cementation solution). It was injected into the slope in a grid pattern of $50 \mathrm{~mm} \times 50 \mathrm{~mm}$ at toe, sloping surface and up to the distance $4 \mathrm{~B}$ from slope crest. This entire slope surface was injected with bacteria solution and cementation solution and allowed to incubate for 14 and 28 days by covering the slope surface with polythene.

The test box with MICP induced slope was brought under a loading frame to conduct the laboratory load test. A strip footing was placed on the slope and away from crest for three different positions on slope (0B, B, 2B). The load was applied at interval on strip footing until failure occurs. The load and corresponding settlement was measured during the entire test. The load settlement curve was plotted for each test and ultimate bearing capacity of strip footing was obtained. Fig. 5 shows experimental setup for strip footing load test conducted on slope incubated for 14 days with footing at B distance from crest.

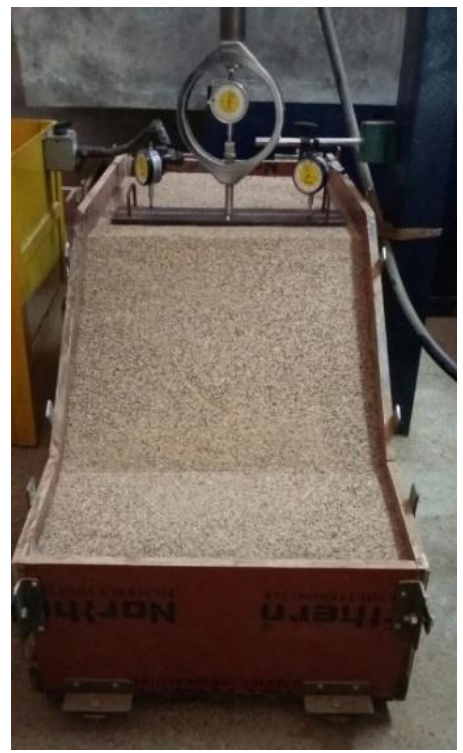

Figure 5: Model Test Setup

\section{Result and Discussion}

In this study, the experimental investigation was carried out on a strip footing by conducting a load test on untreated and MICP treated sand slope of angle 1.5H: $1 \mathrm{~V}$ with footing placed at $0 \mathrm{~B}, \mathrm{~B}$ and $2 \mathrm{~B}$ distance from slope crest. Fig. 6, 7 and 8 shows the load settlement curves of untreated sand slope and MICP treated one with 14 and 28 days incubation. The results were compared with respect to location of footing and incubation period of the treated slope with bacteria and cementation solution.

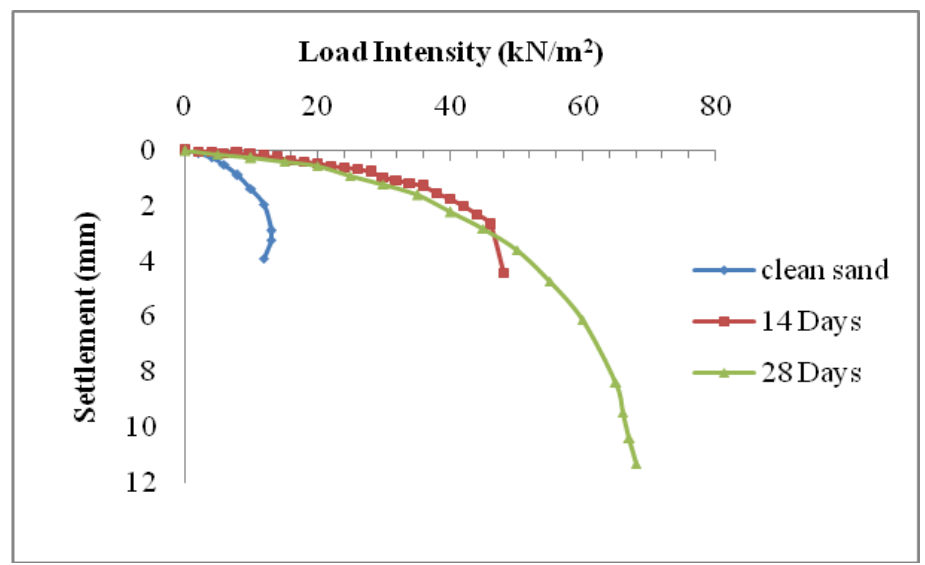

Figure 6: Load Test with Strip Footing at Crest 

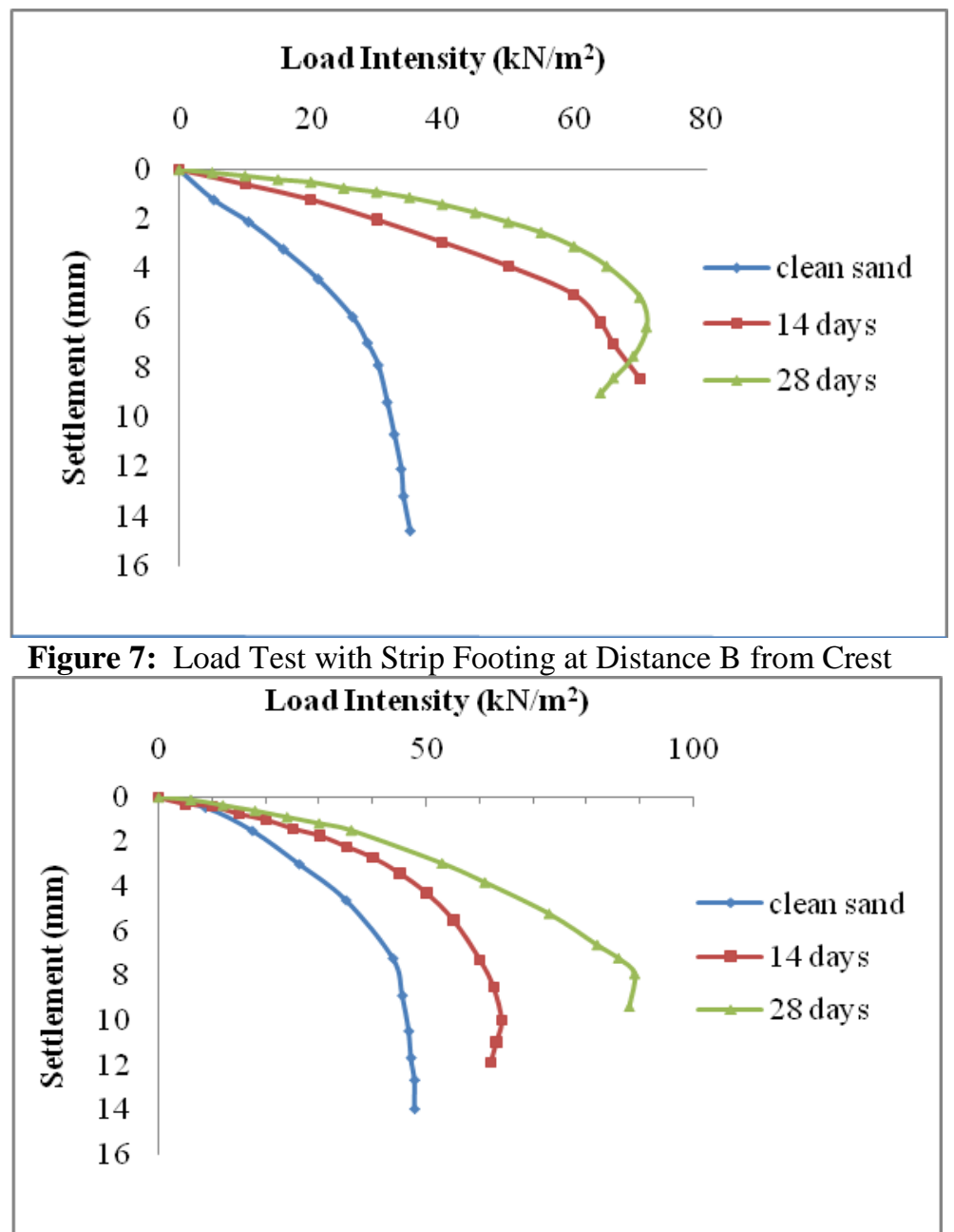

Figure 8: Load Test with Strip Footing at Distance 2B from Crest

The ultimate bearing capacity (UBC) was obtained by drawing tangent intersection on load settleemnt curves in all cases. TABLE 2 gives the ultimate bearing capacity of strip footing for untreated and treated slopes. The bearing capacity ratio (BCR) was calculated by using equation 1 to compare the results. BCR determined for each case is also shown in TABLE 2. BCR indicates that the bearing capacity of strip footing increases when slope is treated with MICP. The maximum increase was observed when footing was palced at crest of slope.

$$
B C R=\frac{U B C_{\text {Treated }}}{U B C_{\text {Untreated }}}
$$

The effect of location of footing on bearing capacity of footing placed on treated sand slope and incubated for 14 and 28 days is summerised in TABLE 3 in terms of \% variation in UBC when strip footing is placed at slope crest. The percentage variation in UBC with respect to crest was determned using equation 2 . It was observed that the bearing capacity increased as the distance of footing increased from the crest of the slope.

$$
\% \text { Increase }=\frac{q_{B}-q_{\text {Crest }}}{q_{\text {crest }}} \times 100
$$

\begin{tabular}{|c|c|c|c|c|c|}
\hline Type & Slope Angle & Incubation Period & Dist. from Crest & $\mathrm{UBC}\left(\mathrm{kN} / \mathrm{m}^{2}\right)$ & BCR \\
\hline \multirow[t]{3}{*}{ Untreated Sand Slope } & \multirow[t]{9}{*}{$1.5 \mathrm{H}: 1 \mathrm{~V}$} & \multirow[t]{3}{*}{-} & 0 & \begin{tabular}{ll|}
13.1 \\
\end{tabular} & \multirow[t]{3}{*}{-} \\
\hline & & & B & 30.15 & \\
\hline & & & $2 \mathrm{~B}$ & 43.8 & \\
\hline \multirow{6}{*}{ Treated Sand Slope } & & \multirow[t]{3}{*}{14 Days } & 0 & 44.0 & 5.00 \\
\hline & & & $\mathrm{B}$ & 55.6 & 2.09 \\
\hline & & & $2 \mathrm{~B}$ & 64.0 & 1.86 \\
\hline & & \multirow[t]{3}{*}{28 Days } & 0 & 58.2 & 6.61 \\
\hline & & & B & 71.0 & 2.68 \\
\hline & & & $2 \mathrm{~B}$ & 88.6 & 2.57 \\
\hline
\end{tabular}

Table 2: UBC of Strip Footing on Slopes 
Table 3: \% Variation in Ultimate Bearing Capacity

\begin{tabular}{|c|c|c|c|}
\hline Slope Angle & $\begin{array}{l}\text { Location of Footing } \\
\text { from Crest }\end{array}$ & Incubation Period & $\begin{array}{c}\text { \% Increase } \\
\text { (With Respect to Crest ) }\end{array}$ \\
\hline \multirow[t]{6}{*}{$1.5 \mathrm{H}: 1 \mathrm{~V}$} & $\mathrm{~B}$ & \multirow[t]{2}{*}{-} & 130.15 \\
\hline & $2 \mathrm{~B}$ & & 234.35 \\
\hline & $\mathrm{B}$ & \multirow[t]{2}{*}{14 Days } & 26.36 \\
\hline & $2 \mathrm{~B}$ & & 45.45 \\
\hline & $\mathrm{B}$ & \multirow[t]{2}{*}{28 Days } & 22.00 \\
\hline & $2 \mathrm{~B}$ & & 52.23 \\
\hline
\end{tabular}

\subsection{Conclusions}

\section{Conclusion}

From the present study of MICP treated slope, following conclusions are drawn;

- The bearing capacity of footing on MICP treated sand slope is significantly increased as compared to untreated slope.

- The behavior of surface strip footing on MICP treated slope is greatly affected by distance of footing from the edge of slope.

- The bearing capacity of a footing situated on the crest of sloping ground is significantly increased when treated with bacteria and cementation solution.

- The bearing capacity of footing increased as the setback distance increased from crest.

- Bearing capacity of footing on MICP treated sand slope is maximum for incubation period of 28 days than 14 days.

\subsection{Application}

The microbial cementation could be used for the following Civil and Geotechnical engineering applications:

- Enhancing stability for retaining walls, embankments and dams.

- Reinforcing or stabilizing soil to facilitate the stability of tunnels or underground constructions.

- In situ ground improvement.

\subsection{Future Scope}

Further study is required on microbial induced calcite precipitation with various types of bacteria for stabilization of slope. There is scope in varying depths of microorganism reinforced sand and using no of treatment at the time of preparation of sample.

\section{References}

[1] Keskin M. S. and Laman M. (2012), Model Studies of Bearing Capacity of Strip Footing on Sand Slope, KSCE Journal of Civil Engineering, 699-71.

[2] Mittal S., Shah M. and Verma N. K. (2009), Experimental Study of Footings on Reinforced Earth Slopes, International Journal of Geotechnical Engineering, Vol 3, 251-260.

[3] DeJong J. T., Fritzges M. B. and Nüsslein K. (2006), Microbially Induced Cementation to Control Sand Response to Undrained Shear, J. Geotechnical and Geoenvironmental Engineering, Vol. 132, 1381-1392.

[4] Mortensen B. M. and DeJong J. T. (2011), Strength and Stiffness of MICP Treated Sand Subjected to Various Stress Paths, GeoFrontiers 2011, 4012-4020.

[5] Soon W., Lee M. and Hii S. L. (2012), An overview of the Factor Affecting MICP and its Potential Application in Soil Improvement, World Academy of Science, Engineering and Technology, 683-689.

[6] Cheng L., Ruwisch R. C., and Shahin M. A., Cementation of Sand Soil by Microbially Induced Calcite Precipitation at Various Degrees of Saturation, Can. Geotech. Journal, (2013), Vol 50, 81-90.

[7] Park S. S., Choi S. G, Kim W. J. and Lee J. C. (2014), Effect of Microbially Induced Calcite Precipitation on Strength of Cemented Sand, New Frontiers in Geotechnical Engineering GSP 243, 47-56.

[8] Soon N. W. and Min L. L. (2014), Factors Affecting Improvement in Engineering Properties of Residual Soil through Microbial Induced Calcite Precipitation, J. Geotechnical and Geoenvironmental Engineering, 04014006-(1-11). 